\title{
BIG4 or Non-BIG4 Auditors: Their Impact on Audit Quality during the Global Financial Crisis
}

\author{
Maria I. Kyriakou*, Augustinos I. Dimitras \\ School of Social Sciences, Hellenic Open University, Patras, Greece \\ Email: *m_kyriakou1@yahoo.gr
}

How to cite this paper: Kyriakou, M.I. and Dimitras, A.I. (2018) BIG4 or Non-BIG4 Auditors: Their Impact on Audit Quality during the Global Financial Crisis. Theoretical Economics Letters, 8, 909-917. https://doi.org/10.4236/tel.2018.85064

Received: February 11, 2018

Accepted: April 6, 2018

Published: April 9, 2018

Copyright ( $) 2018$ by authors and Scientific Research Publishing Inc. This work is licensed under the Creative Commons Attribution International License (CC BY 4.0).

http://creativecommons.org/licenses/by/4.0/

\begin{abstract}
The objective of this paper is to examine the relationship between auditor tenure and discretionary accruals as a proxy of audit quality. The main finding is that this relationship was found to be negative for BIG4 and non-BIG4 auditors in crisis and non-crisis periods, for both German and French companies. In addition, Italian and Spanish companies seem to interplay in crisis and non-crisis periods being either negative or not for BIG4 and non-BIG4 auditors. The findings imply that the larger the country, the better the audit quality and this seems to be confirmed by graphs and statistically by the onesample T-test.
\end{abstract}

\section{Keywords}

BIG4, Non-BIG4, Auditor Tenure, Audit Quality, Financial Crisis, GDP

\section{Introduction}

This paper examines the impact of auditor tenure on audit quality in the four larger economies of the Eurozone during the recent financial crisis. In particular, the countries under study are Germany, France, Italy and Spain and the data cover the period from 2005 to 2013. The study employs discretionary accruals as a proxy of audit quality and is also taking in account the size of the auditors.

The main contribution of this paper is that we analyze the difference in the behaviour of companies audited by a BIG4 or a non-BIG4 auditor under different economic circumstances. For this, we have at first divided the sample of companies into two subsamples: the companies audited by a BIG4 auditor and those audited by a non-BIG4 auditor. As the year that the crisis began is contentious (see Frankel and Saravelos, 2012) [1] we do not consider of a specific year as the beginning of the crisis in all the four countries but for each country (and 
the companies of the country) we follow the proposition by Dimitras et al. (2015) [2] and we consider the countries are in crisis if the change in GDP yearly is negative.

Our results indicate that there is a negative relationship between auditor tenure and discretionary accruals as a proxy of audit quality for two (Germany and France) out of the four countries under investigation in the crisis or non-crisis periods whether audited by a BIG4 auditor or not, being statistically significant as the T-test results indicate. One limitation is that a larger sample would have given more accurate results, however this could be investigated in the near future. In particular, we found that in the crisis period for BIG4 auditors and non-BIG4 auditors in Italian and Spanish companies audit quality was found to decrease, respectively (see Carey and Simnett, 2006) [3]. Our results put emphasis on the theory of audit quality improvement inside or outside the crisis for BIG4 or Non-BIG4 auditors as has been developed by Chen et al. (2008). The article is organized as follows: Section 2 refers to the Literature Review, while Section 3 analyzes the data and presents the methodology. Section 3 analyses the empirical results and finally Section 4 concludes the article and provides the policy implications that arise.

\section{Literature Review}

Gonzalez-Diaz et al. (2015) [4] analyzed the relation between auditor tenure and audit quality in the period 2003-2010 in Spain and concluded that the audit quality was reduced as the auditor tenure was increased, supporting the opinion that the establishment of legislation reduced the auditor tenure in companies under control. Vanstraelen (2000) [5] assumes that the long-term relation between the auditor and audited company increases the possibility substantially so as the auditor to issue a report without prejudices. The results show that the behavior of auditor is different in the first two years of tenure in a company in relation to the auditor's behavior during the last year of their tenure. In particular, the auditor is more willing to issue a negative report in the first two years regardless of the last year of tenure. Thus, it is important the obliged interchange of auditors so as to keep the audit quality and their independence. Ye et al. (2006) [6] concluded that the long-term tenure influences negatively the independence of auditor and therefore the audit quality in relation to short-term tenure. Ghosh and Moon (2005) [7] concluded that there is a positive relation between audit quality and the auditor tenure, which means that the more the auditor tenure the better the independence of auditor and the better the audit quality. Knechel and Vanstraelen (2007) [8] studied the influence of auditor tenure on the audit quality in private companies in Belgium and concluded that the auditor independence is not reduced as the tenure is increased not even is influenced their opinion so as to predict in their reports a possible bankruptcy. In contrast, Ball et al. (2015) [9] believe that the interchange of auditors and therefore the limited tenure will increase the audit quality. In addition, Carey and 
Simnett (2006) [3] studied the effect of long-term tenure on the audit quality. More specifically, they studied a sample of 1021 companies in 1995 in Australia and concluded that the long-term tenure reduces the audit quality when this is counted under the prism of reports with doubt when the auditor issues a report. On the contrary, when they use the discretionary accruals as an indicator of audit quality they did not find an important relation between this and the tenure. Many studies examine the idea that the BIG4 audit companies give higher audit quality than non-big4 audit companies (Geiger and Rama, 2006 [10]; Francis and $\mathrm{Yu}, 2009$ [11]). On the contrary, in Korea, Jeong and Rho (2004) [12] assert that there is no difference in the audit quality among the BIG4 audit companies and non-BIG4 audit companies. The same result found Vander Bauwhede and Willekens (2004) [13] and also Othman and Zeghal (2006) [14].

\section{Data and Methodology}

The dataset was taken from the Datastream database. The sample consisted of 628 German, 628 French, 208 Italian and 112 Spanish companies that do not belong to the financial industry. The period spans from 2005 to 2013.

We employ the Generalized Method of Moments (GMM) estimator proposed by Arellano and Bond (1991) [15] which accounts for all the problems of multiple regressions. So our error term is free of heteroskedasticity, multicollinearity and autocorrelation.

We use the following GMM model.

$$
\begin{aligned}
\text { DAC }_{i, t}= & \alpha_{0}+\alpha_{1} \text { TENURE }_{i, t}+\alpha_{2} \text { OCF }_{i, t}+\alpha_{3} \text { SIZE }_{i, t}+\alpha_{4} \text { LEV }_{i, t} \\
& +\alpha_{5} \text { ROA }_{i, t}+\alpha_{6} \text { DISTRESS }_{i, t}+\alpha_{7} \text { DISTRESS }_{i, t} \\
& +\alpha_{8} \text { DISTRESS }_{i, t}+\varepsilon_{i, t}
\end{aligned}
$$

where,

$T_{E N U R E}$ it, is a dummy variable that takes the value of 1 if the tenure of the auditor is greater than 3 years, otherwise zero. (we suppose that an auditor has a long-term tenure with a company when he or she provides his or her auditing services to the same companies for more than three years without any interruption),

$O C F_{i, t}$ is the operating cash flow,

$S I Z E_{i, t}$ is the natural logarithm of the total assets,

$L E V_{i, t}$ is the sum of liabilities to the total assets,

$R O A_{i, t}$ is the return on assets,

DISTRESS $1_{i, t}$ is a dummy variable that takes the value of 1 if in the current year net profits are negative, otherwise zero (being an indicator of financial distress according to Habib et al:; 2013 [16] and the same holds for the following two variables),

DISTRESS $2_{i, t}$ is a dummy variable that takes the value of 1 if in the current year the working capital is negative, otherwise zero,

DISTRESS $_{i, t}$ is a dummy variable that takes the value of 1 if simultaneously 
in the current year net profits and working capital are negative, otherwise zero and $\varepsilon_{i, t}$ is the error term.

$D A C_{i, t}$ is the dependent variable which measures the discretionary accruals which have been estimated according to the model of Jones (1991) [17] and is equal with the error of the following model, which is introduced by Kothari et al. (2004) [18] and Garza-Gomez et al. (2006) [19]:

$$
A C_{i, t}=\alpha_{0}\left(1 / A_{i, t-1}\right)+\alpha_{1} \Delta R E V_{i, t}+\alpha_{2} P P E_{i, t}+\varepsilon_{i, t}
$$

where, $A C_{i, t}$ is the accrued to the total assets of the previous year, $A_{i, t-1}$ is the total assets of the previous year, $\triangle R E V_{i, t}$ is the annual change of revenues to the total assets of the previous year, $P P E_{i, t}$ is the sum of tangible assets to the total assets of the previous year, and $\varepsilon_{i, t}$ is the error term.

\section{Empirical Results}

The summary statistics in Table 1 show that for both, BIG4 and non-BIG4 auditors, the mean of tenure in crisis periods is larger than the mean of tenure in non-crisis periods. In contrast, standard deviation is larger for the tenure in BIG4 auditors in the crisis period than in the non-crisis period. The opposite holds for the non-BIG4 auditors. This means that there are some small differences and similarities as well in tenure between crisis and non-crisis periods for BIG4 and non-BIG4 auditors.

Table 2 and Table 3 show the impact of auditor tenure on audit quality in German, French, Italian and Spanish companies when the auditor belongs to the BIG4 or non-BIG4 audit companies.

Table 1. Descriptive statistics.

\begin{tabular}{|c|c|c|c|c|}
\hline \multicolumn{5}{|c|}{ Panel A: For BIG4 auditors } \\
\hline & \multicolumn{2}{|c|}{ non-crisis } & \multicolumn{2}{|c|}{ crisis } \\
\hline & Mean & Std. Dev. & Mean & Std. Dev. \\
\hline Germany & 0.43 & 0.49 & 0.69 & 0.46 \\
\hline France & 0.35 & 0.47 & 0.60 & 0.49 \\
\hline Italy & 0.28 & 0.45 & 0.60 & 0.48 \\
\hline Spain & 0.32 & 0.46 & 0.77 & 0.41 \\
\hline \multicolumn{5}{|c|}{ Panel B: For non-BIG4 auditors } \\
\hline & \multicolumn{2}{|c|}{ non-crisis } & \multicolumn{2}{|c|}{ crisis } \\
\hline & Mean & Std. Dev. & Mean & Std. Dev. \\
\hline Germany & 0.32 & 0.46 & 0.51 & 0.50 \\
\hline France & 0.19 & 0.39 & 0.45 & 0.49 \\
\hline Italy & 0.31 & 0.46 & 0.52 & 0.50 \\
\hline Spain & 0.22 & 0.42 & 0.43 & 0.50 \\
\hline
\end{tabular}


Table 2. The impact of auditor tenure on audit quality when auditors belong to BIG4 audit companies

\begin{tabular}{cccc}
\hline & non-crisis & crisis & Difference \\
\hline Germany & -1.422 & -3.101 & -1.629 \\
France & -1.838 & -1.814 & -5.521 \\
Italy & -2.563 & 2.254 & 2.246 \\
Spain & -0.378 & -0.378 & NA \\
\hline
\end{tabular}

Notes: The above values have been calculated as the napierian logarithm of the estimated coefficients of the econometric model. NA means not available.

Table 3. The impact of auditor tenure on audit quality when auditors belong to NonBIG4 audit companies.

\begin{tabular}{cccc}
\hline & non-crisis & crisis & Difference \\
\hline Germany & -1.262 & -2.813 & -1.500 \\
France & -1.832 & -1.456 & -2.617 \\
Italy & -0.597 & -2.103 & -0.848 \\
Spain & -1.207 & 0.309 & 0.062 \\
\hline
\end{tabular}

Notes: The above values have been calculated as the napierian logarithm of the estimated coefficients of the econometric model.

In particular, Table 2 indicates that the impact of auditor tenure on discretionary accruals is negative in both non-crisis and crisis periods with the exception of Italian companies in the crisis period. This means that for all the other countries except Italy, the audit quality has been increased.

In particular, German companies show the largest impact of auditor tenure on audit quality, however only in the crisis period. Italian companies come next, however only in the non-crisis period and then French companies in the noncrisis period and last Spanish companies regardless of the period being inside or outside the crisis. In addition, the napierian logarithm of difference captures the largest impact of French companies on audit quality as it is a negative value with the largest magnitude.

For non-BIG4 auditors, Table 3 shows that the audit quality has been increased mostly in German companies in the crisis period and then in Italian companies in the crisis period as well. However, in the non-crisis period the audit quality has been increased in French and German companies in comparison with the crisis period. The difference is largest for French companies and then for German companies and Italian and Spanish companies follow.

Figure 1 shows the distribution of difference between crisis and non-crisis periods for BIG4 and non-BIG4 auditors. In France both BIG4 and non-BIG4 auditors seem to play an important role, while in Italy only BIG4 auditors do. Non-BIG4 auditors seem to add audit quality in French companies, while the worst audit quality seems to occur in Italian companies with BIG4 auditors.

The above visualised effects are confirmed by the T-test values and its p-values 


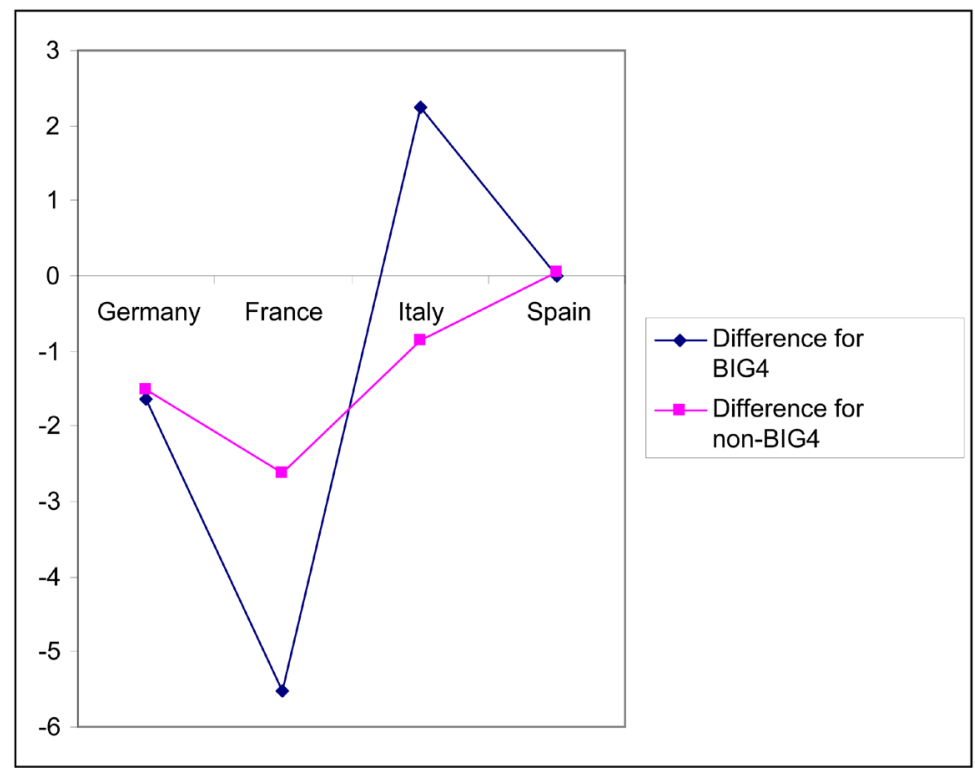

Figure 1. Difference for BIG4 and non-BIG4 auditors.

Table 4. One-Sample T-test Difference for BIG4 and non-BIG4 auditors.

\begin{tabular}{ccc}
\hline & T-value & P-value \\
\hline One-Sample T: Difference for BIG4 & -0.73 & 0.542 \\
One-Sample T: Difference for non-BIG4 & -2.18 & 0.118 \\
\hline
\end{tabular}

for non-BIG4 auditors at the $11.8 \%$ level of significance. The T-test shows that the best audit quality happens in French companies by non-BIG4 auditors, however the T-test results for BIG4 auditors are not statistically significant. The T-test results are displayed above (Table 4).

Figure 2 presents the distribution of audit quality in non-crisis and crisis periods in Germany, France, Italy and Spain when the auditors are BIG4 or non-BIG4, respectively. There are some similarities and some differences in these two distributions of audit quality between BIG4 and non-BIG4 auditors. In particular, this distribution is similar in Germany and France and differs in Italy and Spain.

These effects from Figure 2 are confirmed by the one-sample T-test and its p-values. In particular at the $10 \%$ level of significance, the results of the T-test indicate that there is a difference in the distribution of the audit quality between BIG4 and non-BIG4 auditors, which is due to French and German audit quality differences in both periods (non-crisis and crisis period). The results of the T-test are statistically significant at the $10 \%$ level of significance for both BIG4 and non-BIG4 auditors. The T-test results and its p-values are presented below (Table 5).

The graph in Figure 3 presents the effects of audit quality for BIG4 and non-BIG4 auditors during non-crisis period and crisis period for all countries under investigation, respectively. 


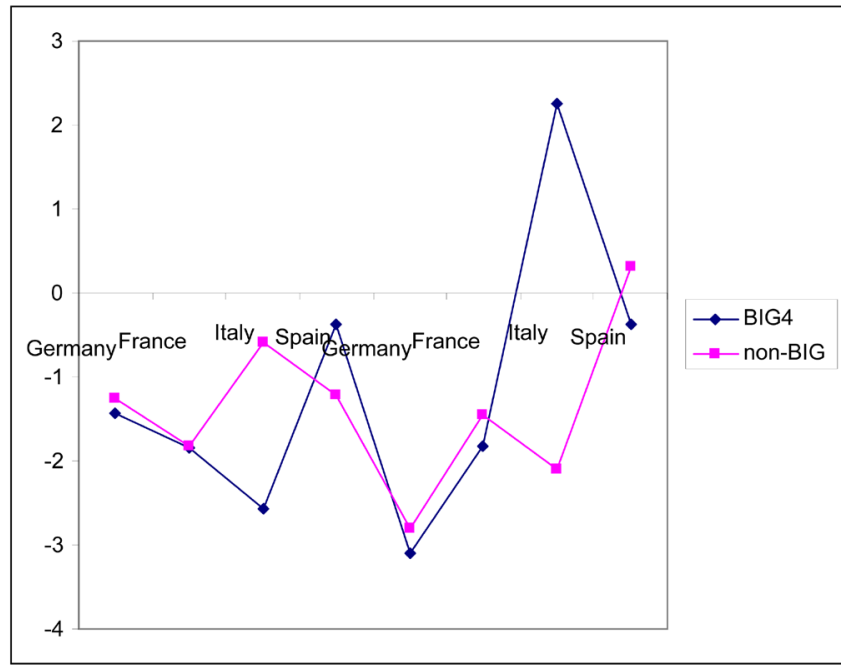

Figure 2. Distribution of the whole period for BIG4 and nonBIG4 auditors.

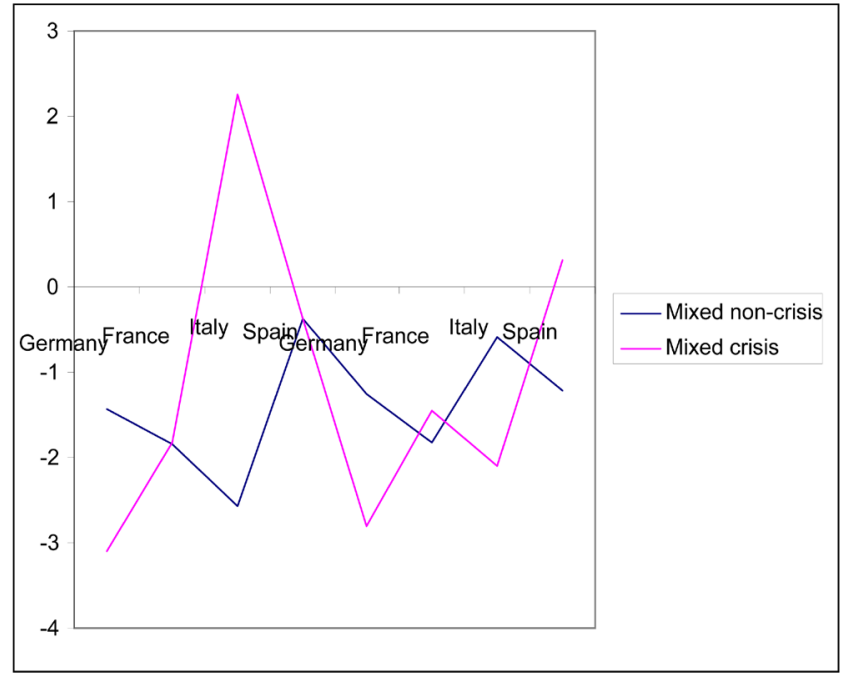

Figure 3. Mixed distribution of non-crisis and crisis periods for BIG4 and non-BIG4 auditors.

Table 5. One-Sample T-test for BIG4 and non-BIG4 auditors on the whole period.

\begin{tabular}{ccc}
\hline & T-value & P-value \\
\hline One-Sample T:BIG4 & -1.95 & 0.092 \\
One-Sample T: non-BIG4 & -4.09 & 0.005 \\
\hline
\end{tabular}

The T-test results indicate that the differences for BIG4 and non-BIG4 auditors are statistically significant at the $1 \%$ level of significance during the non-crisis period, while for BIG4 and non-BIG4 auditors the differences are significant at the $11.5 \%$ level of significance for the crisis period. The results of the T-test and its p-values are presented below (Table 6).

We have performed a robustness check of our results by dividing the whole 
Table 6. One-Sample T-test for mixed distribution of non-crisis and crisis periods for BIG4 and non-BIG4 auditors.

\begin{tabular}{ccc}
\hline & T-value & P-value \\
\hline One-Sample T: non-crisis & -5.57 & 0.001 \\
One-Sample T: crisis & -1.80 & 0.115 \\
\hline
\end{tabular}

period into two investigations in order to examine the stability of our results. The robustness check shows that the impact of auditor tenure on audit quality for BIG4 and non-BIG4 auditors is similar for both the two half investigations and the whole investigation ${ }^{1}$.

Overall, the results indicate that in the crisis period for BIG4 auditors in Italian companies a decrease in audit quality is observed, and in the crisis period for non-BIG4 auditors in Spanish companies a decrease in audit quality is observed. In the other countries, there is an increase in audit quality regardless of crisis or non-crisis periods and BIG4 or non-BIG4 auditors. These results have been seen graphically and confirmed by the one-sample T-test results.

\section{Conclusion and Policy Implications}

Our results confirm the findings of Carey and Simnett (2006). In particular, we found that the relationship of auditor tenure and discretionary accruals is negative in both crisis and non-crisis periods for half of the countries (Germany and France) and this relationship was found to be significant as the statistic metric of one-sample T-test indicates. However, we exceptionally found a positive relationship in the crisis period in Italian and Spanish companies for BIG4 and non-BIG4 auditors, respectively (see Chen et al., 2008) [20]. The economic implications of these findings are that the larger the country the better the impact of auditor tenure on discretionary accruals and thus the better the audit quality, regardless of whether the auditor is BIG4 or non-BIG4 and whether there is crisis or not.

\section{References}

[1] Frankel, J. and Saravelos, G. (2012) Can Leading Indicators Access Country Vulnerability? Evidence from 2008-09 Global Financial Crisis. Journal of International Economics, 87, 216-231. https://doi.org/10.1016/j.jinteco.2011.12.009

[2] Dimitras, A.I., Kyriakou, M.I. and Iatridis, G. (2015) Financial Crisis, GDP Variation and Earnings Management in Europe. Research in International Business and Finance, 34, 338-354. https://doi.org/10.1016/j.ribaf.2015.02.017

[3] Carey, P. and Simnett, R. (2006) Audit Partner Tenure and Audit Quality. The Accounting Review, 81, 653-676. https://doi.org/10.2308/accr.2006.81.3.653

[4] Gonzalez-Diaz, B., García-Fernández, R. and López-Díaz, A. (2015) Auditor Tenure and Audit Quality in Spanish State-Owned Foundation. Revista de ContabilidadSpanish Accounting Review, 18, 115-126.

[5] Vanstraelen, A. (2000) Impact of Renewable Long-Term Audit Mandates on Audit

${ }^{1}$ The results of robustness check are available upon request. 
Quality. The European Accounting Review, 9, 419-442. https://doi.org/10.1080/09638180020017140

[6] Ye, P., Carson, E. and Simnett, R., (2006) Threats to Auditor Independence: The Impact of Non-Audit Services, Tenure and Alumni Affiliation. School of Accounting University of NSW, Sydney.

[7] Ghosh, A. and Moon, D. (2005) Auditor Tenure and Perceptions of Audit Quality. The Accounting Review, 80, 585-612. https://doi.org/10.2308/accr.2005.80.2.585

[8] Knechel, W.R. and Vanstraelen, A. (2007) The Relationship between Auditor Tenure and Audit Quality Implied by Going Concern Opinions. Auditing: A Journal of Practice and Theory, 26, 113-131. https://doi.org/10.2308/aud.2007.26.1.113

[9] Ball, F., Tyler, J. and Wells, P. (2015) Is Audit Quality Impacted by Auditor Relationships? Journal of Contemporary Accounting and Economics, 11, 166-181. https://doi.org/10.1016/j.jcae.2015.05.002

[10] Geiger, M. and Rama, D. (2006) Audit Firm Size and Going-Concern Reporting Accuracy. Accounting Horizons, 20, 1-17. https://doi.org/10.2308/acch.2006.20.1.1

[11] Francis, J. and Yu, M. (2009) Big 4 Office Size and Audit Quality. The Accounting Review, 84, 1521-1552. https://doi.org/10.2308/accr.2009.84.5.1521

[12] Jeong, S. and Rho, J. (2004) Big Six Auditors and Audit Quality: The Korean Evidence. The International Journal of Accounting, 39, 175-196.

https://doi.org/10.1016/j.intacc.2004.02.001

[13] Vander Bauwhede, H. and Willekens, M. (2004) Evidence on (the Lack of) Audit-Quality Differentiation in the Private Client Segment of the Belgian Audit Market. European Accounting Review, 13, 501-522. https://doi.org/10.1080/0963818042000237106

[14] Othman, H.B. and Zeghal, D. (2006) A Study of Earnings-Management Motives in the Anglo-American and Euro-Continental Accounting Models: The Canadian and French Cases. The International Journal of Accounting, 41, 406-435. https://doi.org/10.1016/j.intacc.2006.09.004

[15] Arellano, M. and Bond, S. (1991) Some Tests of Specification for Panel Data Monte Carlo Evidence and an Application to Employment Equations. Review of Economic Studies, 58, 277-297. https://doi.org/10.2307/2297968

[16] Habib, A., Bhuiyan, B. and Islam, A. (2013) Financial Distress, Earnings Management and Market Pricing of Accruals during the Global Financial Crisis. Managerial Finance, 39, 155-180. https://doi.org/10.1108/03074351311294007

[17] Jones, J. (1991) Earnings Management during Import Relief Investigations. Journal of Accounting Research, 29, 193-228. https://doi.org/10.2307/2491047

[18] Kothari, S., Leone, A. and Wasley, C. (2005) Performance Matched Discretionary Accrual Measures. Journal of Accounting and Economics, 39, 163-197. https://doi.org/10.1016/j.jacceco.2004.11.002

[19] Garza-Gomez, X., Lee, Y. and Du, J. (2006) Discretionary Accruals Models and Earnings Restatements: An Empirical Evaluation. Working Paper, University of Houston-Victoria, Victoria, TX.

[20] Chen, C., Lin, C. and Lin, Y. (2008) Audit Partner Tenure, Audit Firm Tenure, and Discretionary Accruals: Does Long-Term Auditor Tenure Impair Earnings Quality? Contemporary Accounting Research, 25, 415-445. https://doi.org/10.1506/car.25.2.5 